\title{
Five-year Survival Predictors for Breast Cancer in Women: A Retrospective Cohort Study
}

\author{
Max Menezesin, Carolina Tavares², Andreia Vaez ${ }^{1,2}$, Paulo Martins-Filho², \\ Ana Almeida ${ }^{3}$, Leila Gonçalves ${ }^{1}$
}

${ }^{1}$ Postgraduate Program in Nursing, Federal University of Sergipe, Brazil. ${ }^{2}$ Investigative Pathology Laboratory, Federal University of Sergipe, Aracaju, Brazil. ${ }^{3}$ São Paulo University, São Paulo, Brazil.

\begin{abstract}
Objective: To analyze predictors of 5-year survival in women with breast cancer in the state of Sergipe. Materials and methods: This is a retrospective cohort study. This study included 100 women aged between 21 and 77 years diagnosed with breast cancer undergoing adjuvant or neoadjuvant chemotherapy in a public tertiary hospital from August 2011 to December 2012. All women were followed up for 5 years or until the date of death. There was no loss in follow-up. Data were collected during the field visit to the specialized health unit and included demographic and socioeconomic variables, tumor staging at diagnosis, patient paths for presentation to health professionals, initial treatment in primary care and treatment. We used a three-stage model: the first ("patient delay"); the second ("delay in diagnosis") and the third ("delay in treatment"). The statistical analysis was performed using the MedCalc version 18 statistical software. The study was approved by the Human Research Ethics Committee of the Federal University of Sergipe (CAAE: 0196.0.107.000-11). Written informed consent was obtained from all participants. Results: Tumor staging [risk ratio $(H R)=3.41, p=0.046$ ] was an independent factor that affected the overall survival curve for women with breast cancer. The overall 5 -year survival rates found for women with tumor staging IA-IIB compared to tumor staging IIIA-IV were $88.5 \%$ and $59.5 \%$, respectively. Through binary logistic regression with forced entry method, it was evident that age $(\mathrm{OR}=2.58, \mathrm{p}=0.050)$, delay in the first stage $(\mathrm{OR}=2.57, \mathrm{p}=0.046)$ and tumor staging $(\mathrm{OR}=3.99, \mathrm{p}=0.042)$ were predictors of mortality in women with breast cancer. Conclusions: Our results highlight the need to strengthen health education actions in primary health care and the implementation of an organized and permanent screening program for the early detection of breast cancer.
\end{abstract}

Keywords: Breast neoplasm- prognosis- survival analysis- primary health care- delayed diagnosis

Asian Pac J Cancer Care, 5 (3), 243-246

Submission Date: 05/10/2020Ａcceptance Date: 08/09/2020

\section{Introduction}

Breast cancer is the most common non-cutaneous malignancy worldwide and the leading cause of cancer death in women. In Brazil, it is estimated nearly 60,000 new cases of breast cancer and 14 deaths per 100,000 women in 2018 [1]. A recent study showed an increased trend of breast cancer mortality in women in Brazil, especially among young women and in the Northeast and Midwest regions [2].

Differences in survival from breast cancer observed seem to be related to socioeconomic inequities and disparities in access to health services which may lead in delay in diagnosis and treatment of disease [3-4].The delay in attention to breast cancer greater than three months between the identification of symptoms and initiation of treatment is considered an important prognostic factor, decreasing by $12 \%$ the survival in five years [5].

In addition actions of screening, diagnosis and treatment should be available to the population independently of their income [6], because the staging profile of women with breast cancer has been characterized by advanced stages of the disease, evidencing the late diagnosis as a national public health issue [7]. We investigated

Corresponding Author:

Dr. Max Menezes

Postgraduate Program in Nursing, Federal University of Sergipe, Brazil.

Email: maxoliver19@hotmail.com 
predictors of 5-year survival in women with breast cancer in Sergipe state.

\section{Materials and Methods}

\section{Design}

Little is known about the influence of survival predictors for breast cancer in the Northeast region, Brazil. In this retrospective cohort study, we investigate predictors of 5-year survival in women with breast cancer in Sergipe state, the smallest federal unit in terms of territory extension $\left(21,918 \mathrm{~km}^{2}\right)$. Sergipe has one of the most incidence rates of breast cancer in Brazil, with 6.34 new cases per 100.000 women [1].

\section{Pacients}

This study included 100 women aged 21-77 years $(51 \pm 10.9$ years $)$ diagnosed as having breast cancer submitted to adjuvant or neoadjuvant chemotherapy in a tertiary-level public hospital from August 2011 to December 2012. All women were followed-up for 5 years or to date of death. There was no loss to follow-up. Data were collected during field visit in the specialized health care unit and included demographic and socioeconomic variables, tumor staging at diagnosis [8], patient pathways to presentation to health care professionals, initial management in primary care, and treatment. We used a three-stage model [9] to account for the total time from first noticing a symptom to beginning treatment. The first stage ("patient delay")was defined as the time the patient first noticing a symptom until to seek professional medical care; the second stage ("diagnosis delay") described the time between the first medical consultation and definitive diagnosis of breast cancer; and the third stage ("treatment delay") included the time between diagnosis and the onset of treatment.

\section{Analyses statistics}

Statistical analysis was performed using MedCalc Statistical Software version 18 (MedCalc Software bvba, Ostend, Belgium; http://www.medcalc.org; 2018). Survival curves were presented as Kaplan-Meier curves, and significance was classified by the log-rank test. The Cox regression model was used for multivariate prognostic analysis, and a binary logistic regression model was used to analyze the influencing clinical factors. Analyses were performed using cutoffs of 30 (patient and diagnosis delay) and 60 (treatment delay) days [10-11]. Eight potential predictors (age, relationship status, years of schooling, income, residence, tumor staging, delay in first, second and third stages) were included in a multifactor analysis using the Cox multivariate regression model with a forced entry method.

\section{Ethical approval}

The study was approved by the Human Research Ethics Committee at the Federal University of Sergipe (CAAE: 0196.0.107.000-11). Informed written consent was obtained from all participants.

\section{Results and Discussion}

The results showed that tumor staging [hazard ratio $(\mathrm{HR})=3.41, \mathrm{p}=0.046]$ was an independent factor affecting the overall survival curve of women with breast cancer (Table 1). The 5-year overall survival rates found for women with tumor staging IA-IIB compared to tumor staging IIIA-IV were $88.5 \%$ and $59.5 \%$, respectively (Figure 1 ). The same eight potential predictors were also analyzed by using a binary logistic regression model with a forced entry method. The results showed that age $(\mathrm{OR}=2.58, \mathrm{p}=0.050)$, delay in first stage $(\mathrm{OR}=2.57, \mathrm{p}=0.046)$, and tumor staging $(\mathrm{OR}=3.99, \mathrm{p}=0.042)$ were predictors for mortality in women with breast cancer (Table 2).

The advanced stage of breast cancer found in this study seems to be the leading prognostic factor for mortality. The 5-year overall survival rates for women with tumor staging IIIA-IV was similar to the found in earlier studies based on different Brazilian cohorts [12-13]. These findings underline the urgent need for structuring services for early-stage breast cancer detection of women with inclusion criteria for screening. In Brazil, women aged 50-69 years have been encouraged to undergo mammography every 2 years, and to have their breasts examined by a physician from 40 years of age [14]. There is evidence of a $20 \%$ relative risk reduction for mortality with mammography at 11 years of follow-up [15]. However, inequalities in health service use in the Northeast Brazil disfavor a regular mammographic screening [16], which may lead in delay in diagnosis of breast cancer.

Despite evidence that young women with breast cancer have a worse prognosis compared to that of middle-aged women even if diagnosed early and receiving intense treatment [17-18], this study showed that age $>50$ years was a predictive factor for mortality, which may be related to the delay in diagnosis, advanced-stage tumor, and less-than-standard treatment. In addition, age-related comorbidities may play a role in the survival rate in this

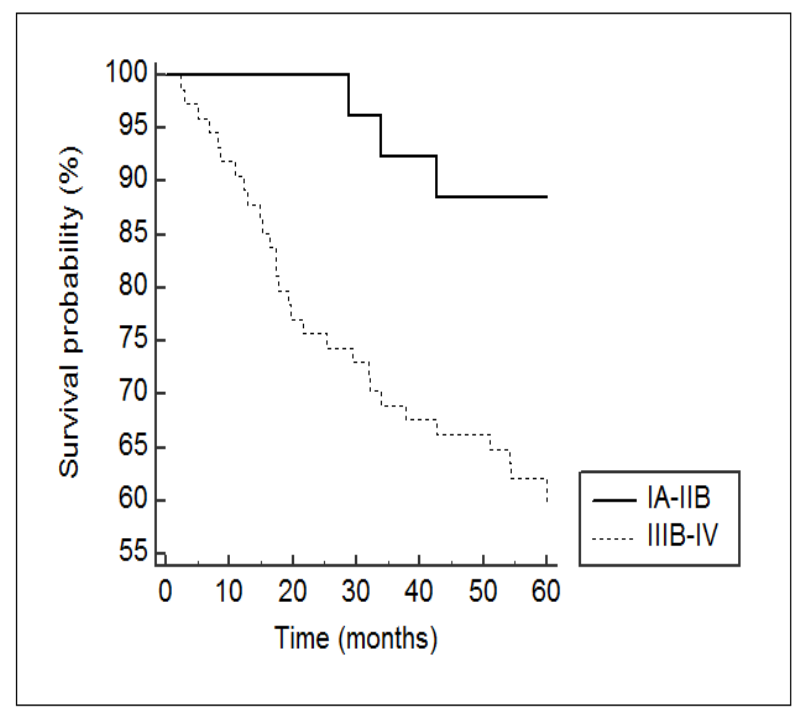

Figure 1. Kaplan-Meir Survival Estimates Based on TNM Stage at the Diagnosis 
Table 1. Results of Log-rank Test and Multivariate Cox Regression Analysis of Clinical Factors in Predicting Overall Survival in Breast Cancer

\begin{tabular}{lcccc}
\hline Characteristic & Log-rank HR $(95 \%$ CI $)$ & p-value & Cox regression HR (95\% CI) & p-value \\
\hline Age $(<50$ years vs. $\geq 50$ years) & $2.10(1.06-4.16)$ & 0.045 & $1.93(0.91-4.07)$ & 0.084 \\
Relationship status & $1.03(0.52-2.06)$ & 0.914 & & \\
(currently single vs. not currently single) & & & & \\
Years of schooling $(<8$ vs. $\geq 8)$ & $1.00(0.48-2.10)$ & 0.993 & \\
Income & $1.32(0.66-2.67)$ & 0.421 & & 0.046 \\
$(<2$ minimum wages vs. $\geq 2$ minimum wages) & & & \\
Residence (state city vs. principal city interior) & $1.43(0.71-2.85)$ & 0.331 & $3.41(1.02-11.32)$ & 0.086 \\
TNM stage (IA-IIB vs. IIIB-IV) & $4.34(2.06-9.11)$ & 0.008 & $1.87(0.92-3.85)$ & \\
Delay in first stage (yes vs. no) & $2.18(1.10-4.32)$ & 0.027 & & \\
Delay in second stage (yes vs. no) & $0.76(0.38-1.52)$ & 0.44 & & \\
Delay in third stage (yes vs. no) & $1.09(0.55-2.17)$ & 0.79 & & \\
\hline
\end{tabular}

HR, hazard ratio; CI, confidence interval.

Table 2. Results of Logistic Regression Analysis of Association between Clinical Factors and Death in Breast Cancer.

\begin{tabular}{|c|c|c|c|c|}
\hline Characteristic & Univariate OR $(95 \% \mathrm{CI})$ & p-value & Multivariate OR $(95 \% \mathrm{CI})$ & p-value \\
\hline Age $(<50$ years vs. $\geq 50$ years $)$ & $2.52(1.04-6.09)$ & 0.041 & $2.58(1.00-6.67)$ & 0.05 \\
\hline $\begin{array}{l}\text { Relationship status } \\
\text { (currently single vs. not currently single) }\end{array}$ & $1.09(0.47-2.53)$ & 0.837 & & \\
\hline Years of schooling $(<8$ vs. $\geq 8)$ & $0.98(0.39-2.43)$ & 0.963 & & \\
\hline $\begin{array}{l}\text { Income } \\
(<2 \text { minimum wages vs. } \geq 2 \text { minimum wages })\end{array}$ & $1.40(0.60-3.26)$ & 0.435 & & \\
\hline Residence (state city vs. principal city interior) & $1.43(0.60-3.43)$ & 0.416 & & \\
\hline TNM stage (IA-IIB vs. IIIB-IV) & $5.23(1.44-18.98)$ & 0.012 & $3.99(1.05-15.13)$ & 0.042 \\
\hline Delay in first stage (yes vs. no) & $2.76(1.16-6.54)$ & 0.021 & $2.57(1.02-6.48)$ & 0.046 \\
\hline Delay in second stage (yes vs. no) & $0.68(0.29-1.56)$ & 0.359 & & \\
\hline Delay in third stage (yes vs. no) & $1.09(0.48-2.52)$ & 0.832 & & \\
\hline
\end{tabular}

population. Unfortunately, the expression of predictive molecular biological markers for breast cancer prognosis and that are age-dependent were not evaluated and constitute an intrinsic limitation of study design.

Moreover, the present study found an association between the delay in seeking medical attention after self-discovering a potential breast cancer symptom and mortality. Patient delay maybe associated to health behavior, including lack of breast self-examination and general health care utilization, and socioeconomic factors such as old age and ethnicity. In addition, non-attribution of symptoms to cancer, fear of the disease and treatment and low educational level seem to be frequent causes of patient delay [19]. Interestingly, it has been showed that older women are more prone to procrastinate early detection of breast cancer resulting in more advanced disease and fewer a symptomatic cases [20]. Our findings highlight the need to strengthen actions for health education in primary health care and the implementation of an organized and permanent screening program for early detection of breast cancer.

\section{References}

1. INCA. Estimativa 2018: Incidência de Câncer no Brasil 2018. 2018..

2. Rocha-Brischiliari SC, Oliveira RRD, Andrade L, Brischiliari A, Gravena AAF, Carvalho MDDB, Pelloso SM. The Rise in Mortality from Breast Cancer in Young Women: Trend Analysis in Brazil. Ahmad A. PLOS ONE. 2017 01 03;12(1):e0168950. https://doi.org/10.1371/journal. pone. 0168950

3. Guerra MR, Silva GAE, Nogueira MC, Leite ICG, Oliveira RDVCD, Cintra JRD, Bustamante-Teixeira MT. Sobrevida por câncer de mama e iniquidade em saúde. Cadernos de Saúde Pública. 2015 08;31(8):1673-1684. https://doi. org/10.1590/0102-311x00145214

4. Ferraz RDO, Moreira-Filho DDC. Análise de sobrevivência de mulheres com câncer de mama: modelos de riscos competitivos. Ciência \& Saúde Coletiva. 2017 Nov;22(11):3743-3754. https://doi.org/10.1590/1413812320172211.05092016

5. Richards M, Westcombe A, Love S, Littlejohns P, Ramirez A. Influence of delay on survival in patients with breast cancer: a systematic review. The Lancet. 1999 04;353(9159):11191126. https://doi.org/10.1016/s0140-6736(99)02143-1

6. Farmer P, Frenk J, Knaul FM, Shulman LN, Alleyne G, Armstrong L, Atun R, Blayney D, Chen L, Feachem R, Gospodarowicz M, Gralow J, Gupta S, Langer A, Lob-Levyt 
J, Neal C, Mbewu A, Mired D, Piot P, Reddy KS, Sachs JD, Sarhan M, Seffrin JR. Expansion of cancer care and control in countries of low and middle income: a call to action. The Lancet. 2010 Oct;376(9747):1186-1193. https://doi. org/10.1016/s0140-6736(10)61152-x

7. Panis C, Cecílio-da-Silva AP, Takakura ET, Jumes JJ, Willhelm-dos-Santos J, Herrera AC, Victorino VJ. Breast cancer in Brazil: epidemiology and treatment challenges. Breast Cancer: Targets and Therapy. 2015 01;:43. https:// doi.org/10.2147/bctt.s50361

8. Edge S, Byrd D, Compton C, et al. AJCC Cancer Staging Manual. New York: Springer. 2009. Available from: https:// www.springer.com/gp/book/9780387884424.

9. Andersen BL, Cacioppo JT, Roberts DC. Delay in seeking a cancer diagnosis: Delay stages and psychophysiological comparison processes. British Journal of Social Psychology. 1995 03;34(1):33-52. https://doi. org/10.1111/j.2044-8309.1995.tb01047.x

10. Brasil. Ministério da Saúde. Lei no 12.732, de 22 de novembro de 2012. 2012. Dispõe sobre o primeiro tratamento de paciente com neoplasia maligna comprovada e estabelece prazo para seu início . Available from: http:// www.planalto.gov.br/ccivil_03/_ato2011-2014/2012/lei/ 112732.htm.

11. Brasil. Câmara dos Deputados. Atividade Legislativa/ Projetos de Lei e Outras Proposições/PL 275/2015. 2015. Available from: http://www.camara.gov.br/proposicoesWeb/ fichadetramitacao?idProposicao $=946293 \% 3$.

12. Ayala ALM. Sobrevida de mulheres com câncer de mama, de uma cidade no sul do Brasil. Revista Brasileira de Enfermagem. 2012 08;65(4):566-570. https://doi. org/10.1590/s0034-71672012000400003

13. Balabram D, Turra CM, Gobbi H. Survival of patients with operable breast cancer (Stages I-III) at a Brazilian public hospital - a closer look into cause-specific mortality. BMC Cancer. 201309 24;13(1). https://doi.org/10.1186/14712407-13-434

14. Passman LJ, Ramalho Ortigão Farias AM, Tomazelli JG, Franco de Abreu DM, Dias MBK, de Assis M, de Almeida PF, Ferreira da Silva RC, Santini LA. SISMAMAImplementation of an information system for breast cancer early detection programs in Brazil. The Breast. 2011 04;20:S35-S39. https://doi.org/10.1016/j.breast.2011.02.001

15. WHO. WHO Position Paper on Mammography Screening. Geneva: World Health Organization; 2014. Annex B, Evidence Summary: Benefits and harms of mammography screening: umbrella systematic review. Available from: https://www.ncbi.nlm.nih.gov/books/NBK269537/..

16. Melo ECP, de Oliveira EXG, Chor D, Carvalho MS, Pinheiro RS. Inequalities in socioeconomic status and race and the odds of undergoing a mammogram in Brazil. International Journal for Equity in Health. 201609 15;15(1). https://doi. org/10.1186/s12939-016-0435-4

17. Benz CC. Impact of aging on the biology of breast cancer. Critical Reviews in Oncology/Hematology. 2008 04;66(1):65-74. https://doi.org/10.1016/j. critrevonc.2007.09.001

18. Fredholm H, Eaker S, Frisell J, Holmberg L, Fredriksson I, Lindman H. Breast Cancer in Young Women: Poor Survival Despite Intensive Treatment. Aziz SA. PLoS ONE. 2009 Nov 11;4(11):e7695. https://doi.org/10.1371/journal. pone.0007695

19. Freitas AGQ, Weller M. Patient delays and system delays in breast cancer treatment in developed and developing countries. Ciência \& Saúde Coletiva. 2015 Oct;20(10):3177-3189. https://doi.org/10.1590/1413-
812320152010.19692014

20. Arndt V, Stürmer T, Stegmaier C, Ziegler H, Dhom G, Brenner H. Patient delay and stage of diagnosis among breast cancer patients in Germany - a population based study. British Journal of Cancer. 2002 04;86(7):1034-1040. https://doi.org/10.1038/sj.bjc.6600209

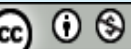

This work is licensed under a Creative Commons AttributionNon Commercial 4.0 International License. 